\title{
EFFECT OF ESSENTIAL OIL BLEND ON INTESTINAL MORPHOLOGY, GUT MICROBIOTA AND IMMUNE RESPONSE OF BROILER CHICKENS
}

\author{
S. PARVEEN ${ }^{1}$, G. P. MANDAL ${ }^{1 *}$, I. SAMANTA ${ }^{2}$, A. K. PATRA ${ }^{1}$, \\ S. SOREN ${ }^{1}$ AND B. ROY ${ }^{1}$
}

${ }^{1}$ Department of Animal Nutrition, West Bengal University of Animal \& Fishery Sciences,
Kolkata-700 037, West Bengal, India
${ }^{2}$ Department of Veterinary Microbiology, West Bengal University of Animal \& Fishery Sciences,
Kolkata-700 037, West Bengal, India

\begin{abstract}
A study was conducted with the objectives to explore the effect of an essential oil (EO) blend containing cinnamon oil, clove oil and ajwain oil at equal ratio on intestinal morphology, gut microbiota and immune response of broiler chickens fed diet deficient in digestible amino acids. Total two hundred eighty eight $(n=288)$ day-old mixed sex Vencobb 400 broiler chickens were randomly divided into four experimental groups comprising of eight replicates each. Each replicate contained nine (9) birds. Birds were fed a positive control diet (PC), negative control diet (NC, $5 \%$ less digestible amino acids than $\mathrm{PC}$ ), $\mathrm{NC}+\mathrm{EO}$ blend at $250 \mathrm{mg} / \mathrm{kg}$ diet (EO250), NC+ EO blend at $500 \mathrm{mg} / \mathrm{kg}$ diet (EO500) for 39 days. On day 39, one bird from each replicate was slaughtered for intestinal sample collection. The villi height in duodenum was significantly increased $(\mathrm{P}<0.05)$ in EO500 group compared to PC and NC groups. The counts of $E$ coli, Lactobacillus spp. and Clostridium spp. in precaecal digesta were not affected $(\mathrm{P}>\mathbf{0 . 0 5})$ by dietary treatments. The antibody titers against Newcastle disease (ND) vaccine were higher $(\mathbf{P}<0.001)$ in EOs supplemented groups in comparison to PC and NC groups. Supplementation of EO at $500 \mathrm{mg} / \mathrm{kg}$ diet increased $(\mathrm{P}<0.05)$ catalase activity in serum, while superoside dismutase (SOD) activity was not affected by dietary treatments. It is concluded that essential oils could be used to improve the gut morphology and immunity in broiler chickens.
\end{abstract}

Key words: Broiler chickens, Essential oil, Gut microbiota, Immune response, Intestinal morphology

\section{INTRODUCTION}

Essential oils (EOs) have attracted most attention in recent years in poultry industry because they can improve digestion, nutrient utilization, and may have a potential to promote nutrient sparing effect. Many studies have observed that EOs positively affect the morphology of small intestine, such as increased villus height and number of goblet cells (Jang et al., 2007). Such effect on gut morphology has been shown to improve nutrient digestibility and growth performance (Hernandez et al., 2004). Essential oils may possess various biological properties, such as antimicrobials properties (Cowan, 1999; Ultee et al., 1999), antioxidant and anti-inûammatory activities (Viuda-Martos et al., 2010) and immunomodulating properties (Chowdhury et al., 2018). Thus, EOs can be used as growth promoters in poultry production.

\footnotetext{
*Corresponding Author
} 
Nevertheless, some studies reported negative or no effect of EOs on growth performance, intestinal morphology and gut microbiota (Muhl, 2007; Abildgaard et al., 2010; Hafeez et al., 2016). The inconsistent results were mainly attributed to dose, source and type of EOs and composition of EOs (Cross et al., 2007; Buchanan et al., 2008). In-vitro studies also suggested that combination of EOs has a greater effect than individual EOs alone, indicating a synergy between individual chemical of EOs (Burt, 2004; Lee et al., 2004). Though there are substantial research works on EOs in broiler chickens, the studies on effect of EOs in poultry fed on diet deficient in nutrients are limited. We hypothesized that EOs blend may be capable of sparing nutrients by improving gut health leading to euobiosis. Therefore, the aim of the present study was to investigate the effect of EOs blend on gut microbiota, intestinal morphology, immunity and antioxidant status of broiler chickens fed on amino acids deficient diets.

\section{MATERIALS AND METHODS}

The Institutional Animal Ethics Committee of West Bengal University of Animal and Fishery Sciences, Kolkata, India approved the experimental procedures that were followed as per the guidelines of the Committee for the Purpose of Control and Supervision on Experiments on Animals (CPCSEA), Government of India.

Two hundred eighty eight $(\mathrm{n}=288)$ day-old mixed sex Vencobb 400 broiler chicks were randomly divided into four experimental groups comprising of eight replicates each. Each replicate contained nine birds. Corn and soybean based positive control (PC) diets were formulated to meet the requirements of the birds according to the breed specifications (Table 1). The negative control diets were prepared by reducing digestible amino acids content by $5 \%$ as compared to PC (Table 2). The dietary groups were consisted of 1) PC- basal diet without any additive; 2) NC- basal diet containing $5 \%$ less digestible amino acids; 3) EO250- NC diet supplemented with EO blend at the rate of 250 $\mathrm{mg} / \mathrm{kg}$ diet; 4) EO500- NC diet supplemented with EO blend at the rate of $500 \mathrm{mg} / \mathrm{kg}$ diet. The doses of the EOs were decided based on our in vitro study using pure pathogenic culture of Escherichia coli and Salmonella gallinarum isolated from chickens. Essential oils were obtained from a local store, Kolkata, India. A blend was made by cinnamon oil, clove oil and ajwain oil by mixing at equal ratio. No antibiotics were added to diets. The blend of EOs was mixed with the NC diet homogenously. The diet and water were provided ad libitum. The blended mash feed was packed in separate labeled HDPE (high density polythene) bags with inner lining. All the birds were vaccinated against Newcastle disease (ND) at 5 and 20 days of age, and infectious bursal disease (IBD) at 14 days of age.

Feed samples were analyzed for proximate composition (AOAC, 1995) and calcium (Talapatra et al., 1940). At 28 and 35days of experimental trial, blood sample $(2 \mathrm{~mL})$ was collected with the help of sterile syringes and needles by Vena brachialis puncture under the wing from one bird from each replicate, centrifuged and serum was stored in a deep freeze at $-20^{\circ} \mathrm{C}$ for analysis of antibody titers and antioxidant status of the broiler chickens. The antibody titers against ND vaccine on day 28 and 35 were measured by using a commercial ELISA kit (x-OvO limited, United Kingdom).The activities of catalase (Beers and Sizer, 1952) and superoxide dismutase (SOD) (Misra and Fridovich, 1972) in serum samples were measured colorimetrically following standard procedures.

At day 39, one bird from each replicate was slaughtered by cervical disarticulation for measurement of intestinal morphology, bacterial count and lymphoid organs. The small intestine was removed and 2 to $3 \mathrm{~cm}$ sections of duodenum, jejunum (between the entry of bile duct and Mackel's diverticulum) and ileum were removed, rinsed with phosphate buffer saline (PBS) and cross 
Table 1. Ingredient and nutrient composition of the positive control diets (digestible amino acids as per requirements)

\begin{tabular}{|c|c|c|c|}
\hline & $\begin{array}{c}\text { Starter } \\
(\text { day } 1-14)\end{array}$ & $\begin{array}{c}\text { Grower } \\
(\text { day } 15-28)\end{array}$ & $\begin{array}{c}\text { Finisher } \\
\text { (day } 29-39)\end{array}$ \\
\hline \multicolumn{4}{|l|}{ Ingredient composition (\%) } \\
\hline Maize & 55.003 & 57.049 & 60.507 \\
\hline Soya bean meal & 38.045 & 34.546 & 30.568 \\
\hline Veg. oil & 2.772 & 4.456 & 5.116 \\
\hline Dicalcium phosphate & 1.745 & 1.616 & 1.547 \\
\hline Lime stone phosphate & 1.210 & 1.262 & 1.224 \\
\hline Salt & 0.323 & 0.325 & 0.327 \\
\hline DL-Methionine & 0.310 & 0.250 & 0.222 \\
\hline L-Lysin & 0.283 & 0.197 & 0.188 \\
\hline L-Threonine & 0.033 & 0.023 & 0.026 \\
\hline Toxin binder ${ }^{1}$ & 0.050 & 0.050 & 0.050 \\
\hline Sodium bi carbonate & 0.100 & 0.100 & 0.100 \\
\hline Choline chloride & 0.050 & 0.050 & 0.050 \\
\hline Organic trace mineral premix ${ }^{2}$ & 0.050 & 0.050 & 0.050 \\
\hline vitamin primix $^{3}$ & 0.015 & 0.015 & 0.015 \\
\hline Antioxidant ${ }^{4}$ & 0.010 & 0.010 & 0.010 \\
\hline \multicolumn{4}{|l|}{ Nutrient composition } \\
\hline Metabolizable energy $(\mathrm{kcal} / \mathrm{kg})^{5}$ & 3000 & 3125 & 3200 \\
\hline Crude protein $(\%)^{6}$ & 22.50 & 21.00 & 19.50 \\
\hline Ether extract $(\%)^{6}$ & 5.21 & 6.92 & 7.66 \\
\hline Calcium $(\%)^{6}$ & 0.94 & 0.92 & 0.88 \\
\hline Dig. Lysine $(\%)^{5}$ & 1.25 & 1.10 & 1.00 \\
\hline Dig. Methionine $(\%)^{5}$ & 0.62 & 0.54 & 0.49 \\
\hline Dig. Methionine + Dig. Cysteine $(\%)^{5}$ & 0.90 & 0.81 & 0.75 \\
\hline Dig. Threonine $(\%)^{5}$ & 0.77 & 0.71 & 0.66 \\
\hline
\end{tabular}

${ }^{1}$ Niltox ${ }^{\mathrm{TM}}$, Zeus Biotech Limited, Mysore, India; ${ }^{2}$ Contains (per kg): Zn proteinate- $50 \mathrm{~g}$, Fe proteinate- $30 \mathrm{~g}, \mathrm{Cu}$ proteinate- $10 \mathrm{~g}$, Se proteinate- $0.5 \mathrm{~g}$, Mn proteinate- $50 \mathrm{~g}, \mathrm{I}-4 \mathrm{~g}$, Cu proteinate- $0.4 \mathrm{~g}$ (Zeus Biotech Limited, Mysore, India); ${ }^{3}$ Contains (per kilogram): vitamin A- 80,000,000 IU, vitamin $\mathrm{D}_{3}-16,000,000$ I.U, vitamin E- $64 \mathrm{~g}$, vitamin $\mathrm{K}-8 \mathrm{~g}$, vitamin $\mathrm{B}_{1}-6.4 \mathrm{~g}$, vitamin $\mathrm{B}_{2}-40 \mathrm{~g}$, niacin- $96 \mathrm{~g}$, pantothenic acid- $64 \mathrm{~g}$, vitamin $\mathrm{B}_{6}-12.8 \mathrm{~g}$, folic acid- $6.4 \mathrm{~g}$, vitamin $\mathrm{B}_{12}-0.164 \mathrm{~g}$ and biotin- $0.24 \mathrm{~g}$; ${ }^{4}$ Endox, Kemin Industries, Inc., USA, ${ }^{5}$ Calculated values; ${ }^{6}$ Analysed values

sectional lengths of $1 \mathrm{~cm}$ were fixed in $10 \%$ buffered formaldehyde ( $\mathrm{pH}$ 7.2), followed by embedding in paraffin wax. The slides with the tissue sections were then stained with Delafield's Hematoxyline and Eosin, and mounted on distrene plasticiser xylene (DPX) as per the protocol described by Kumar et al. (2017). The villi height and crept length were measured using an ocular micrometer (under a microscope fitted with a stage micrometer) and image analysis 
Table 2. Ingredient and nutrient composition of the negative control diets (5\% less digestible amino acids)

\begin{tabular}{|c|c|c|c|}
\hline & $\begin{array}{c}\text { Starter } \\
\text { (day } 1-14)\end{array}$ & $\begin{array}{c}\text { Grower } \\
\text { (day } 15-28) \\
\end{array}$ & $\begin{array}{c}\text { Finisher } \\
\text { (day } 29-39)\end{array}$ \\
\hline \multicolumn{4}{|l|}{ Ingredient composition (\%) } \\
\hline Maize & 58.707 & 60.528 & 63.638 \\
\hline Soya bean meal & 34.804 & 31.499 & 27.772 \\
\hline Veg. oil & 2.268 & 3.982 & 4.705 \\
\hline Dicalcium phosphate & 1.780 & 1.649 & 1.577 \\
\hline Lime stone powder & 1.214 & 1.266 & 1.227 \\
\hline Salt & 0.324 & 0.326 & 0.365 \\
\hline DL-Methionine & 0.293 & 0.232 & 0.202 \\
\hline L-Lysine & 0.301 & 0.222 & 0.206 \\
\hline L-Threonine & 0.035 & 0.022 & 0.032 \\
\hline Toxin binder ${ }^{1}$ & 0.050 & 0.050 & 0.050 \\
\hline Sodium bi carbonate & 0.100 & 0.100 & 0.100 \\
\hline Choline chloride & 0.050 & 0.050 & 0.050 \\
\hline Trace mineral premix ${ }^{2}$ & 0.050 & 0.050 & 0.050 \\
\hline Vitamin primix ${ }^{3}$ & 0.015 & 0.015 & 0.015 \\
\hline Antioxidant $^{4}$ & 0.010 & 0.010 & 0.010 \\
\hline \multicolumn{4}{|l|}{ Nutrient composition } \\
\hline Metabolizable energy $(\mathrm{kcal} / \mathrm{kg})^{5}$ & 3000 & 3125 & 3200 \\
\hline Crude protein $(\%)^{6}$ & 21.38 & 19.95 & 18.53 \\
\hline Ether extract $(\%)^{6}$ & 4.82 & 6.55 & 7.35 \\
\hline Calcium $(\%)^{6}$ & 0.94 & 0.92 & 0.88 \\
\hline Dig. Lysine $(\%)^{5}$ & 1.19 & 1.05 & 0.95 \\
\hline Dig. Methionine $(\%)^{5}$ & 0.59 & 0.51 & 0.46 \\
\hline Dig. Methionine + Dig. Cysteine $(\%)^{5}$ & 0.86 & 0.77 & 0.71 \\
\hline Dig. Threonine $(\%)^{5}$ & 0.73 & 0.67 & 0.63 \\
\hline
\end{tabular}

${ }^{1}$ Niltox $^{\mathrm{TM}}$, Zeus Biotech Limited, Mysore, India; ${ }^{2}$ Contains (per kg): Zn proteinate- $50 \mathrm{~g}$, Fe proteinate- $30 \mathrm{~g}, \mathrm{Cu}$ proteinate- $10 \mathrm{~g}$, Se proteinate- $0.5 \mathrm{~g}, \mathrm{Mn}$ proteinate- $50 \mathrm{~g}, \mathrm{I}-4 \mathrm{~g}$, Cu proteinate- $0.4 \mathrm{~g}$ (Zeus Biotech Limited, Mysore, India); ${ }^{3}$ Contains (per kilogram): vitamin A- 80,000,000 IU, vitamin $\mathrm{D}_{3}-16,000,000 \mathrm{I} . \mathrm{U}$, vitamin E- $64 \mathrm{~g}$, vitamin $\mathrm{K}-8 \mathrm{~g}$, vitamin $\mathrm{B}_{1}-6.4 \mathrm{~g}$, vitamin $\mathrm{B}_{2}-40 \mathrm{~g}$, niacin- $96 \mathrm{~g}$, pantothenic acid- $64 \mathrm{~g}$, vitamin $\mathrm{B}_{6}-12.8 \mathrm{~g}$, folic acid- $6.4 \mathrm{~g}$, vitamin $\mathrm{B}_{12}{ }^{-} 0.164 \mathrm{~g}$ and biotin- $0.24 \mathrm{~g} ;{ }^{4}$ Endox, Kemin Industries, Inc., USA, ${ }^{5}$ Calculated values; ${ }^{6}$ Analysed values

software (Biowizard 4.2, Dewinter Optical and New Delhi, India).

The pre-caecal contents of the intestine were aseptically collected from the birds after slaughter on day 39 of the trial. After removal, the pre-caecal contents were stored at $4{ }^{\circ} \mathrm{C}$, and bacteriological enumeration was performed on the same day. One gram of the pre-caecal content was serially diluted (10-fold) with PBS. From $10^{-4}$ and $10^{-5}$ 
dilution, $10 \mu \mathrm{L}$ was placed on eosin methylene bule (EMB) agar (HiMedia, Mumbai, India), Clostridial agar (HiMedia, Mumbai, India) and Lactobacilli Agar (HiMedia, Mumbai, India), for culture of E. coli, Clostridium, Lactobacilli spp., respectively. The plates were incubated aerobically at $37^{\circ} \mathrm{C}$ for $24 \mathrm{~h}$ except for Lactobacillus which was incubated for $48 \mathrm{~h}$. Clostridial agar plates were incubated at $37^{\circ} \mathrm{C}$ anaerobically. The colonies for each pathogen were enumerated in a colony counter (hand held digital colony counter, LA663, Himedia Lab. Pvt. Ltd., Mumbai, India) and the numbers were expressed as $\log _{10}$ colony forming units (CFU) per gram of sample.

The data were analyzed by one way analysis of variance (ANOVA) using SPSS (1997) in a completely randomized design with a model containing treatments as the effect. Single pen was used as an experimental unit. Probability values of $\mathrm{P}>0.05$ were declared as significant and the values of $\mathrm{P}>0.05$ but $\leq 0.10$ were declared as trend. When treatment effect was significant, the difference among the treatment mean were detected using Duncan's multiple range test.

\section{RESULTS}

Intestinal morphology and microbiota: Intestinal morphology is presented in Table 3. The villi height in duodenum was significantly increased in EO500 group compared to $\mathrm{NC}(\mathrm{P}<0.05)$, while no differences were observed among PC, EO250 and $\mathrm{EO} 500$ groups. A trend $(\mathrm{P}<0.1)$ in greater villi height in jejunum was observed in EO500 group than other groups.

The villi height in ileum was not affected by treatments $(\mathrm{P}>0.05)$. The crypt length in duodenum, jejunum and ileum was same across the groups. The $\mathrm{VH} / \mathrm{CD}$ ratio was similar in all groups $(\mathrm{P}>0.05)$. The pre-caecal bacterial count of birds was shown in Table 4. The counts of E coli, Lactobacillus spp. and Clostridium spp. were not affected $(\mathrm{P}>0.05)$ by dietary treatments.

Immune response and antioxidant enzymes: Antibody titres against ND vaccine on day 28 were higher $(\mathrm{P}<0.001)$ in EOs supplemented group in comparison to $\mathrm{PC}$ and $\mathrm{NC}$ groups, while the increment was higher in EO500 than EO250 (Table 5). On day 35, antibody titres were higher $(\mathrm{P}<0.01)$ in EO500 than $\mathrm{PC}, \mathrm{NC}$, however no

Table 3. Effect of essential oil supplementation on intestinal morphology $(\mu)$ in broiler chickens

\begin{tabular}{|c|c|c|c|c|c|c|}
\hline \multirow[t]{2}{*}{ Attribute } & \multicolumn{4}{|c|}{ Treatment } & \multirow[t]{2}{*}{ SEM } & \multirow[t]{2}{*}{ P- value } \\
\hline & PC & $\mathbf{N C}$ & EO250 & $\mathbf{E O 5 0 0}$ & & \\
\hline \multicolumn{7}{|l|}{ Duodenum } \\
\hline Villi height (Vh) & $1247^{\mathrm{ab}}$ & $1194^{\mathrm{b}}$ & $1247^{\mathrm{ab}}$ & $1343^{\mathrm{a}}$ & 19.55 & $0.049 *$ \\
\hline Crypt depth (CD) & 68.68 & 68.09 & 73.02 & 70.46 & 1.743 & 0.572 \\
\hline $\mathrm{Vh} / \mathrm{CD}$ ratio & 18.92 & 18.27 & 17.27 & 19.23 & 0.516 & 0.568 \\
\hline \multicolumn{7}{|l|}{ Jejunum } \\
\hline$\overline{\mathrm{Vh}}$ & 1028 & 989 & 1007 & 1109 & 18.02 & 0.085 \\
\hline $\mathrm{CD}$ & 62.74 & 67.75 & 64.41 & 65.78 & 1.418 & 0.662 \\
\hline $\mathrm{Vh} / \mathrm{CD}$ ratio & 16.51 & 14.80 & 15.74 & 17.08 & 0.389 & 0.184 \\
\hline \multicolumn{7}{|l|}{ Ileum } \\
\hline$\overline{\mathrm{Vh}}$ & 828 & 761 & 817 & 801 & 11.36 & 0.172 \\
\hline $\mathrm{CD}$ & 56.04 & 57.28 & 61.34 & 64.93 & 1.453 & 0.115 \\
\hline $\mathrm{Vh} / \mathrm{CD}$ ratio & 14.99 & 13.61 & 13.65 & 12.50 & 0.453 & 0.295 \\
\hline
\end{tabular}

$*(\mathrm{P} \leq 0.05)$, Means bearing different superscripts in the same row differ significantly 
Table 4. Effect of supplementation of essential oil on viable bacteria numbers $\left(\log _{10} \mathrm{CFU} / \mathrm{g}\right)$ in precaecal content in broiler chickens

\begin{tabular}{|c|c|c|c|c|c|c|}
\hline \multirow[t]{2}{*}{ Precaecal bacteria } & \multicolumn{4}{|c|}{ Treatment } & \multirow[t]{2}{*}{ SEM } & \multirow[t]{2}{*}{ P-value } \\
\hline & $\overline{P C}$ & $\mathrm{NC}$ & EO250 & EO500 & & \\
\hline Escherichia coli & 5.66 & 5.41 & 5.73 & 5.84 & 0.100 & 0.522 \\
\hline Lactobacillus spp. & 5.37 & 5.44 & 5.81 & 5.83 & 0.098 & 0.207 \\
\hline Clostridium spp. & 5.88 & 5.84 & 5.95 & 5.62 & 0.085 & 0.571 \\
\hline
\end{tabular}

Table 5. Effect of essential oil supplementation on antibody titre $\left(\log _{10}\right)$ against Newcastle disease vaccine, weight of lymphoid organs and antioxidant enzyme activities in broiler chickens

\begin{tabular}{|c|c|c|c|c|c|c|}
\hline \multirow[t]{2}{*}{ Attribute } & \multicolumn{4}{|c|}{ Treatment } & \multirow[t]{2}{*}{ SEM } & \multirow[t]{2}{*}{ P-value } \\
\hline & PC & $\mathrm{NC}$ & EO250 & $\mathbf{E O 5 0 0}$ & & \\
\hline \multicolumn{7}{|l|}{ Antibody titre } \\
\hline day 28 & $877^{\mathrm{c}}$ & $994^{\mathrm{c}}$ & $1660^{\mathrm{b}}$ & $2620^{\mathrm{a}}$ & 172.83 & $0.001^{* *}$ \\
\hline day 35 & $2868^{\mathrm{b}}$ & $2593^{\mathrm{b}}$ & $3503^{\mathrm{ab}}$ & $4267^{\mathrm{a}}$ & 200.67 & $0.007^{* *}$ \\
\hline \multicolumn{7}{|l|}{ Lymphoid organs } \\
\hline Liver $(\mathrm{g})$ & 50.03 & 46.99 & 47.59 & 51.60 & 0.956 & 0.295 \\
\hline Liver (\% of SBW) & 2.90 & 2.83 & 2.81 & 3.06 & 0.049 & 0.264 \\
\hline Spleen $(\mathrm{g})$ & 1.93 & 2.08 & 1.81 & 2.38 & 0.094 & 0.149 \\
\hline Spleen $(\%)$ of SBW & 0.11 & 0.12 & 0.11 & 0.14 & 0.006 & 0.084 \\
\hline Bursa (g) & 1.99 & 1.54 & 1.80 & 2.07 & 0.108 & 0.321 \\
\hline Bursa (\% of SBW) & 0.12 & 0.09 & 0.11 & 0.12 & 0.006 & 0.370 \\
\hline \multicolumn{7}{|l|}{ Antioxidant enzymes } \\
\hline Catalase $(\mathrm{U} / \mathrm{mL})$ & $9.83^{b}$ & $15.99^{\mathrm{b}}$ & $23.02^{a b}$ & $36.55^{\mathrm{a}}$ & 3.016 & $0.006^{* *}$ \\
\hline $\mathrm{SOD}(\mathrm{U} / \mathrm{mL})$ & 178.34 & 172.12 & 176.80 & 167.59 & 2.325 & 0.364 \\
\hline
\end{tabular}

${ }_{* *}(\mathrm{P} \leq 0.01)$, Means bearing different superscripts in the same row differ significantly

differences were observed between EO250 and EO500 group. The weight and percent of slaughter body weight (SBW) of lymphoid organs was similar $(\mathrm{P}>0.05)$ across treatments. (Table 5). However, a trend $(\mathrm{P}<0.1)$ in higher percent of SBW of spleen was observed in EO500 group. The catalase activity was higher $(\mathrm{P}<0.01)$ in EO500 than PC and NC, while no differences were observed between EO250 and EO500 groups. However, the SOD activity was similar $(\mathrm{P}>0.05)$ among the groups (Table 5).

\section{DISCUSSION}

In this study, villi hight of duodenum was significantly increased by EO supplementation (500 mg/kg diet). A trend in greater villi height in jejunum due to supplementation of $500 \mathrm{mg}$ EO blend/kg diet was also noted. The higher villi height leads to more surface area for absorption of nutrients which, in turn, results in better digestion and absorption of nutrients (Murugesan et al., 2014). This result is similar with the result of Khattak et al. (2014) who reported that supplementation of a commercial feed additive $(300 \mathrm{mg} / \mathrm{kg}$ ) containing a blend of EO from basil, caraway, laurel, lemon, oregano, sage, tea, and thyme increased villi height of intestine. Similarly, Chowdhury et al. (2018) reported that 
villi height of duodenum and jejunum was increased following supplementation of cinnamon oil at $300 \mathrm{mg} / \mathrm{kg}$. The beneficial effects of EO blend on intestinal morphology might be associated with their anti-inflammatory effects, which in turn, protect the villi from oxidative damage (Du et al., 2016).

The present study showed that the EO blend was ineffective to alter the precaecal bacterial counts. Chowdhury et al., (2018) also reported that supplementation of cinnamon oil at $300 \mathrm{mg} / \mathrm{kg}$ diet, clove oil at $600 \mathrm{mg} / \mathrm{kg}$ diet or ajwain oil at $400 \mathrm{mg} / \mathrm{kg}$ diet did not alter the counts of Clostridium spp. and Lactobacillus spp., while count of $E$. coli was lowered, Similarly, Ahsan et al. (2018) observed that dietary supplementation of different levels of a commercial phytogenic feed additive containing cinnamon, cumin, peppermint oil, garlic oil, anise oil, fennel oil caused no differences in counts of E. coli, Lactobacilli and Coliforms. Most essential oils exert their in vitro antibacterial activity at dose level of 0.03 to $2 \%$ (Hammer et al., 1999). However, EOs are supplemented in diet much lower levels than those required for in vitro antibacterial activity (Hafeez et al., 2016). Therefore, the dose of EO blend in present study may not sufficient enough to exert antimicrobial activity.

Antibody titres against ND vaccine on day 28 and 35 were significantly higher owing to supplementation of EO blend at $500 \mathrm{mg} / \mathrm{kg}$ diet. This finding is similar as reported by Chowdhury et al., (2018), where supplementation of cinnamon oil at $300 \mathrm{mg} / \mathrm{kg}$ diet, clove oil at $600 \mathrm{mg} / \mathrm{kg}$ diet or ajwain oil at $400 \mathrm{mg} / \mathrm{kg}$ diet increased antibody titres against ND vaccine in broiler chickens. Sadeghi et al. (2012) reported that dietary supplementation of cinnamon oil increased antibody titers against ND vaccine in broiler

\section{REFERENCES}

Abildgaard L, Hoijberg O, Schramm A, Balle KM and Engberg RM, 2010. The effect of feeding a commercial essential oil product on chickens. Similarly, a commercial product containing mixture of oregano oil, carvacrol, thyme oil, eucalyptus oil, thymol and eucalyptol added at $0.5 \mathrm{~mL} / \mathrm{L}$ of drinking water improved humoral immune response against ND vaccine (El-Shall et al., 2020). Though the exert mechanism by which EOs stimulate immune response is largely unknown. It is postulated that the active component of EOs may act as additional ligands of $\mathrm{Fc}$ receptors of IgG molecules, which bind to IgG and stimulate the immune response (Nimmerjahn and Ravetch, 2010; Ahmed et al., 2013).

The catalase activity was significantly increased by EO blend supplementation at $500 \mathrm{mg} / \mathrm{kg}$ diet, while SOD activity was not affected by EO blend supplementation. This result is in agreement with Gumus et al. (2017) who reported that supplementation of thyme essential oil at 150 , 300 or $450 \mathrm{mg} / \mathrm{kg}$ diet increased serum catalase activity in Japanese quails. Lee et al. (2020) observed that supplementation of EO blend (an equal concentration of thymol and carvacrol) at 60 or $120 \mathrm{mg} / \mathrm{kg}$ diet did not affect serum catalase and SOD activities in broiler chickens. The antioxidant activity of EOs may be due to their ability to prevent lipid peroxidation, scavenging free radicals or, and in a few cases, chelating metal ions (Miguel, 2010).

Supplementation of EO blend containing cinnamon oil, clove oil and ajwain oil in equal proportion at $500 \mathrm{mg} / \mathrm{kg}$ to a diet deficient in digestible amino acids significantly increased villi height in duodenum, antibody titres against ND vaccine and serum catalase activity in broiler chickens. Therefore, it is concluded that essential oils could be used to improve the gut morphology and immunity in broiler chickens fed on amino acids deficient diet.

Clostridium perfringens numbers in the intestine of broiler chickens measured by realtime PCR targeting the $\alpha$-toxin- enconding 
gene (plc). Anim Feed Sci Technol, 157(3-4): 181-189, doi: 10.1016/j.anifeedsci. 2010.03.010

Ahmed ST, Hossain ME, Kim GM, Hwang JA, Ji H et al., 2013. Effects of resveratrol and essential oils on growth performance immunity, digestibility and fecal microbial shedding in challenged piglets. Asian-Australas J Anim Sci, 26(5): 683-690, doi: 10.5713/ajas.2012.12683

Ahsan U, Kuter E, Raza I, Köksal BH, Cengiz Ö et al., 2018. Dietary supplementation of different levels of phytogenic feed additive in broiler diets: the dynamics of growth performance, caecal microbiota, and intestinal morphometry. Braz J Poult Sci, 20(4): 737-746, doi: 10.1590/ 1806-9061-2017-0698

AOAC, 1995. Official Methods of Analysis, $16^{\text {th }}$ edn., Association of Official Analytical Chemists, Arlington, VA

Beers Jr RF and Sizer IW, 1952. A spectrophotometric method for measuring the breakdown of hydrogen peroxide by catalase. J Biol Chem, 195: $133-140$

Buchanan NP, Hott JM, Cutlip SE, Rack AL, Asamer A et al., 2008. The effects of a natural antibiotic alternative and a natural growth promoter feed additive on broiler performance and carcass quality. J Appl Poult Res, 17(2): 202-210, doi: 10.3382/japr.2007-00038

Burt S, 2004. Essential oils: their antibacterial properties and potential applications in foods - A review. Int J Food Microbiol, 94(3): 223253, doi: 10.1016/j.ijfoodmicro.2004.03.022

Chowdhury S, Mandal GP, Patra AK, Kumar P, Samanta I et al., 2018. Different essential oils in diets of broiler chickens: 2. Gut microbesand morphology, immune response, and some blood profile and antioxidant enzymes. Anim Feed Sci Technol, 236: 39-47, doi: 10.1016/ j.anifeedsci.2017.12.003

Cowan MM, 1999. Plant products as antimicrobial agents. Clin Microbiol Rev, 12(4): 564-582, doi: 10.1128/CMR.12.4.564

Cross DE, McDevitt RM, Hillman K and Acamovic T, 2007. The effect of herbs and their associated essential oils on performance: dietary digestibility and gut microflora in chickens from 7 to 28 days of age. Br Poult Sci, 48(4): 496-506, doi: 10.1080/00071660701463221

Du E, Wang W, Gan L, Li Z, Guo S et al., 2016. Effects of thymol and carvacrol supplementation on intestinal integrity and immune responses of broiler chickens challenged with Clostridium perfringens. J Anim Sci Biotechnol, 7: 19, doi: 10.1186/s40104-016-0079-7

El-Shall NA, Shewita RS, Abd El-Hack ME, AlKahtane A, Alarifi S et al., 2020. Effect of essential oils on the immune response to some viral vaccines in broiler chickens, with special reference to Newcastle disease virus. Poult Sci, 99(6): 29442954, doi: 10.1016/j.psj.2020.03.008

Gumus R, Ercan N and Imik H, 2017. The effect of thyme essential oil (Thymus vulgaris) added to quail diets on performance, some blood parameters, and the antioxidative metabolism of the serum and liver tissues. Rev Bras Cienc Avic, 19(2): 297-304, doi: 10.1590/18069061-2016-0403

Hafeez A, Manner K, Schieder C and Zentek J, 2016. Effect of supplementation of phytogenic feed additives (powdered vs. encapsulated) on performance and nutrient digestibility in broiler chickens. Poult Sci, 95(3): 622-629, doi: $10.3382 / \mathrm{ps} / \mathrm{pev} 368$

Hammer KA, Carson CF and Riley TV, 1999. Antimicrobial activity of essential oils and other plant extracts. J Appl Microbiol, 86(6): 985-990, doi: 10.1046/j.13652672.1999.00780.x

Hernandez F, Madrid J, Garcia V, Orengo J and Megias MD, 2004. Influence of two plants extracts on broiler performance, digestibility and digestive organ size. Poult Sci, 83(2): 169-174, doi: 10.1093/ps/83.2.169

Jang IS, Ko YH, Kang SY and Lee CY, 2007. Effect of a commercial essential oil on growth performance, digestive enzyme activity and intestinal microflora population in broiler chickens. Anim Feed Sci Technol, 134(3-4): 304-315, doi: 10.1016/j.anifeedsci. 2006.06.009 
Khattak F, Ronchi A, Castelli P and Sparks N, 2014. Effects of natural blend of essential oil on growth performance, blood biochemistry, cecal morphology, and carcass quality of broiler chickens. Poult Sci, 93(1): 132-137, doi: 10.3382/ps.2013-03387

Kumar P, Patra AK, Mandal GP, Samanta I and Pradhan S, 2017. Effect of black cumin seeds on growth performance, nutrient utilization, immunity, and gut health in broiler chickens. J Sci Food Agric, 97(11): 3742-3751, doi: 10.1002/ jsfa. 8237

Lee JW, Kim DH, Kim YB, Jeong SB, Oh ST et al., 2020. Dietary encapsulated essential oils improve production performance of coccidiosis-vaccine-challenged broiler chickens. Animals (Basel), 10(3): 481, doi: 10.3390/ani10030481

Lee KW, Everts H, Kappert HJ, Van Der Kuilen J, Lemmens AG et al., 2004. Growth performance, intestinal viscosity, fat digestibility and plasma cholesterol in broiler chickens fed a ryecontaining diet without or with essential oil components. Int J Poult Sci, 3(9): 613-618, doi: $10.3923 /$ ijps.2004.613.618

Miguel MG, 2010. Antioxidant and anti-inflammatory activities of essential oils: A short review. Molecules, 15(12): 9252-9287, doi: 10.3390/ molecules 15129252

Misra HP and Fridovich I, 1972. The role of superoxide anion in the autooxidation of epinephrine and a simple assay for superoxide dismutase. J Biol Chem, 247(10): 3170-3175

Muhl A and Liebert F, 2007. Growth, nutrient utilization and threonine requirement of growing chicken fed threonine limiting diets with commercial blends of phytogenic feed additives. J Poult Sci, 44(3): 297-304, doi: 10.2141/jpsa.44.297

Murugesan GR, Gabler NK and Persia ME, 2014. Effects of direct-fed microbial supplementation on broiler performance, intestinal nutrient transport and integrity under experimental conditions with increased microbial challenge. Br Poult Sci, 55(1): 89-97, doi: 10.1080/00071668. 2013.865834

Nimmerjahn F and Ravetch JV, 2010. Antibodymediated modulation of immune responses. Immunolog Rev, 236(1): 265-275, doi: 10.1111/j.1600-065X.2010. 00910.x

Sadeghi GH, Karimi A, Padidar JSH, Azizi T and Daneshmand A, 2012. Effects of cinnamon, thyme and turmeric infusions on the performance and immune response in of 1-21 day-old male broilers. Rev Bras Ciênc Avíc, 14(1): 15-20, doi: 10.1590/S1516$635 \times 2012000100003$

SPSS Inc, 1997. SPSS Base 7.5 for Windows User's Guide. Prentice Hall

Talapatra SK, Roy SC and Sen KC, 1940. The analysis of mineral constituents in biological materials. I. Estimation of phosphorus, calcium, magnesium, sodium and potassium in food stuffs. Indian J Vet Sci, 10: 243-258

Ultee A, Kets EPW and Smith EJ, 1999. Mechanisms of action of carvacrol on the food borne pathogen Bacillus cereus. Appl Environ Microbiol, 65(10): 4606-4610

Viuda-Martos M, Ruiz-Navajas Y, Fernández-López J and Pérez-Álvarez JA, 2010. Spices as functional foods. Crit Rev Food Sci Nutr, 51(1): 13-28, doi: 10.1080/ 10408390903044271 